\section{EFFECTS OF SPEED AND AGILITY TRAININGS AT YOUNG FOOTBALL PLAYERS}

\section{UČINCI TRENINGA BRZINE I AGILNOSTI KOD MLADIH NOGOMETAŠA}

\section{ABSTRACT}

The goal of this research is to determine the progress in development of speed, agility and explosiveness in young footballers. The research was conducted on a sample of 25 young footballers aged 9.50 \pm 0.50 , height $143,4 \pm 6,6 \mathrm{~cm}$ and weight $33,5 \pm 7,9 \mathrm{~kg}$. The respondents are members of the football club "NK Sloga" from Ljubuski, who are trained in the age category "Limaci (U-11)". A total of 3 tests were applied: 1. Running at 20 meters from the high start (Tr20m); 2. Running back and forth with a change of $90^{\circ}(\operatorname{TrNN})$; 3. Zigzag running between poles (TrZZ). An analysis of the differences (T-test) between initial and final measurements resulted in an improvement in the results. The average result of the initial $20 \mathrm{~m}$ run measurement is 4,43 seconds while the average result of the final measurement is better for 10 hundredths and is 4,33 seconds. In the zig-zag test, the average score of the initial measurement was 9,34 seconds, while the final result was 9,1 seconds. The average score was improved by 0,24 hundredths. In a $180^{\circ}$ shift running, respondents ran averaged 14.37 seconds in the initial measurement, or 14,08 seconds in the final measurement.The average score improved by 0,29 hundredths. Correlation analysis found that there was a statistically significant connection between all three tests. The highest connection between the two different tests was measured at the initial measurement of the run test with $180^{\circ}$ change of direction and the final measurement at the 20m running test and it was 0,89.

Keywords: training, speed, agility, young football players 


\section{INTRODUCTION}

Football is one of the most popular sports games of today. Given the popularity of football, the interest in this kind of activity is present in children and their parents. Football training in children is a complex process that is based on the adoption and implementation of specific sets of movements and actions of the football game, and therefore requires a special treatment of their training (Mrsic and Jerković, 2010). Success in football requires a large number of skills, qualities and knowledge, the most important of which are the anthropological characteristics, specific skills and knowledge of football players, and situational efficiency and results in the competition (Dujmovic, Elsner and Fiorentini, 2000). The training of younger age groups should be focused on motor and psychological development and motivation for physical activity rather than the early expectation of sporting results in children (Jukic, 2016), because early achievements can endanger emotional, physical or creative aspects of child development (Spock and Parker, 1998) . In this research, we elaborated development of speed and agility of young footballers. In a study conducted by Jozak, Segedi, Despot, Marceic, Sos and Ivanjko (2010), the results showed that there are significant changes in $20 \mathrm{~m}$ sprint tests and agility at $4 \times 8$ meters, primarily due to improvement of unning technique, range of training, and development of coordination. Samija (2011) determines changes in morphological characteristics, motor and functional abilities created under an influence of specific speed and agility training (SAQ) for junior footballers, and results show that there are statistically significant changes in the experimental group in all variables, while tere are statistically significant changes in morphological variables in the control group, and on variables for assessing agility, explosive strength the type of sprint, flexibility and on the variable for assessing aerobic endurance, a very small decrease or stagnation of the assessed abilities is found. Jukic (2016) explores the differences between a selected and non-selected group of young footballers of the same age in motor skills and abilities. According to the results, children in the selected football group and open school do not differ in motor skills and abilities except in the beep test.

Many studies have shown that there is no statistically significant correlation, namely that speed and agility are relatively independent attributes of professional football players Buttifant, Graham and Cross (2001), Little and Williams (2003), Sporis, Milanovic, Trajkovic and Joksimovic (2011). The aforementioned researches also show that basic skills without a ball have a greater correlation with speed, agility and explosiveness than ball skills.

A review of literature shows that significant changes in the test results occur for speed and agility, and that speed and agility show relatively low correlation in the patterns of senior football players. In addition, the difference in success in the performance of speed and agility tests with ball and without the ball is noticeable. Most of the previous research has been devoted more to professional footballers or older ages, and for this reason, this research has been carried out to determine the progress in speed and agility development and to establish the correlation between speed and agility in young footballers aged 9,5 $\pm 0,5$.

\section{METHODS}

In this study, the respondents of 25 young footballers aged 9,5 $\pm 0,5$ years, height $143,4 \pm 6,6 \mathrm{~cm}$, and mass $33,5 \pm 7,9 \mathrm{~kg}$ were included. The respondents are members of the football club "NK Sloga" from Ljubuski, age category "Limaci (U-11)". They trained twice a week and they competed at weekends in "!Hej U-11 League". The football experience in the club was 1 to 3 years.

Experimental training was conducted twice a week for 8 weeks, with initial and final measurement performed one week before or after treatment. Trainings took place in the open,

Pokrajčić, V., Herceg, L., \& Dugonjić, B., Vojvodić, M. (2018). Effects of speed and agility trainings at young football players. Sportlogia, 14 (1), 59-65. doi:10.5550/sgia.181401.en.phd 
in the main playground of the "Babovac" stadium in Ljubuski with natural grass. In addition to other aids (ladders, pins, poles, circles, hurdles), the respondents were training with the ball no. 4 (lighter and smaller than the standard size). The treatment was performed in the period from 17 Oct until 18 Dec 2017. The trainings took place in the afternoon at 14:00. The training lasted approx. 60 mins and consisted of three parts: introductory-preparation (25 $\mathrm{min})$, main part (30 min) and final part (5-10 min). Experimental treatments were not done during the whole training but only in the introductory - preparatory part of the training (20 minutes). The sample of variables in this research was obtained from three tests: $T r 20 \mathrm{~m}$ running at 20 meters from high start, TRZZ - zig-zag running between poles and $\operatorname{Tr} 180^{\circ}$ running with $180^{\circ}$ change of direction.

Measures of morphological characteristics (height and weight) were obtained by applying basic anthropological instruments (centimeter tape and scale). The tests were recorded with a high-frequency camera and were then analyzed and measured in the Kinove program. Values are expressed by hundredths of seconds. Measurement was carried out at the city stadium "Babovac" in Ljubuski. The results of the research were processed in the program Statistica 13. Descriptive statistics were used to determine the descriptive parameters of the initial and final measurements. The distribution regularity was determined by Kolmogorov-Smirnov test. The dependent T-test was used to determine the differences between the initial and final measurements, while correlation analysis was used to determine the correlation between all three tests.

\section{RESULTS AND DISCUSSION}

Table 1 shows the results of the descriptive statistics of the initial and final measurements obtained in $\operatorname{Tr} 20 \mathrm{~m}, \operatorname{TrZZ}$ and $\operatorname{Tr} 180^{\circ}$ tests. The average result of the initial measurement of the $\operatorname{Tr} 20 \mathrm{~m}$ test is 4,43 seconds while the average result of the final measurement is better for 10 hundredths and is 4,33 . The results ranged from 3,9 to 4,92 seconds in the initial measurement, or 3,86-4,93 seconds in the final measurement. For $\operatorname{TrZZ}$ test results it is apparent that they are in the range from 8,53 to 10,84 seconds in initial measurement, ie. 8 to 10,71 seconds in the final measurement. The average result of the initial measurement was 9,34 and the final 9,1 seconds. In $\operatorname{Tr} 180^{\circ}$ test, the respondents ran 14,37 seconds on average in initial measurement, ie. 14,08 seconds in final measurement. The best result of the initial measurement was 12,76 seconds, and of the final 12,58 , while the worst result of the initial measurement was 16,44 seconds and of the final 16,21 seconds. We determined by KS test that distribution does not deviate significantly from normal distribution and we continued with further processing of data.

Table 1 - Descriptive parameters of the results achieved in the initial and final measurement $(N=25)$

\begin{tabular}{cccccc} 
Variables & Mean & Min & Max & SD & MaxD \\
\hline Tr20m I & 4,43 & 3,9 & 4,92 & 0,27 & 0,120397 \\
Tr20m F & 4,33 & 3,86 & 4,93 & 0,28 & 0,139811 \\
TrZZ I & 9,34 & 8,53 & 10,84 & 0,63 & 0,135993 \\
$\operatorname{TrZZ~F}$ & 9,1 & 8 & 10,71 & 0,63 & 0,124699 \\
$\operatorname{Tr} 180^{\circ} \mathrm{I}$ & 14,37 & 12,76 & 16,44 & 1,01 & 0,093553 \\
$\operatorname{Tr} 180^{\circ} \mathrm{F}$ & 14,08 & 12,58 & 16,21 & 0,92 & 0,098470 \\
\hline \hline
\end{tabular}

LEGEND: Mean - arithmetic mean; Min - minimal result; Max - maximum result; SD standard deviation; MaxD - distribution normality

Pokrajčić, V., Herceg, L., \& Dugonjić, B., Vojvodić, M. (2018). Effects of speed and agility trainings at young football players. Sportlogia, 14 (1), 59-65. doi:10.5550/sgia.181401.en.phd 
Table 2 shows the average results of the initial and final measurement in the $\operatorname{Tr} 20 \mathrm{~m}$ test. In the initial measurement, the average score is 4,43 seconds, while the final measurement result is 4,33 seconds. On average, the score was improved for 10 hundredths. The standard deviation is 0,27 at the initial, 0,28 at the final, which tells us how much on average the elements of the set deviate from the arithmetic mean. Based on an error of less than 0,05 , we can say that there are statistically significant differences between initial and final measurements.

Table 2 - T-test for dependent patterns for determining the difference between initial and final measurements in 20 m running

\begin{tabular}{ccccc} 
Variables & $\mathrm{N}$ & Mean & SD & $\mathrm{p}$ \\
\hline $\operatorname{Tr} 20 \mathrm{~m} \mathrm{I}$ & 25 & 4,43 & 0,27 & \multirow{2}{*}{0,00} \\
$\operatorname{Tr} 20 \mathrm{~m} \mathrm{~F}$ & 25 & 4,33 & 0,28 & \\
\hline \hline
\end{tabular}

LEGEND: N - number of respondents; Mean - arithmetic mean; SD - standard deviation; $p$ - level of significance

Table 3 shows the average results of the initial and final measurement of the TRZZ test. At initial measurement, the average result was 9,34 seconds, and in the final measurement 9,1 seconds. The average score of this test improved by 0,24 hundredths. The standard deviation is 0,63 for both measurements. Based on an error of less than 0,05, we can say that there are statistically significant differences between initial and final measurements.

Table 3 - T-test for dependent samples for determining the difference between initial and final measurements in zig-zag running

\begin{tabular}{ccccc} 
Variables & $\mathrm{N}$ & Mean & SD & $\mathrm{p}$ \\
\hline TrZZ I & 25 & 9,34 & 0,63 & \multirow{2}{*}{0,00} \\
TrZZ F & 25 & 9,1 & 0,63 & \\
\hline \hline
\end{tabular}

LEGEND: N - number of respondents; Mean - arithmetic mean; SD - standard deviation; $p$

- level of significance

Table 4 shows the average results of initial and final measurement in the $\operatorname{Tr} 180^{\circ}$ test. The average result of the initial measurement was 14,37 seconds, while of the final measurement it was 14,08 seconds. And we note here the improvement of the mean value results for 0,29 hundredths. The standard deviation at the initial measurement was 1,01 , while at the final measurement it was 0,92 . Based on an error of less than 0,05 , we can say that there are statistically significant differences between initial and final measurements.

Pokrajčić, V., Herceg, L., \& Dugonjić, B., Vojvodić, M. (2018). Effects of speed and agility trainings at young football players. Sportlogia, 14 (1), 59-65. doi:10.5550/sgia.181401.en.phd 
Table 4 - T-test for dependent samples for determining the difference between initial and final measurements in running with $180^{\circ}$ direction change

\begin{tabular}{ccccc} 
Variables & N & Mean & SD & p \\
\hline $\operatorname{Tr} 180^{\circ} \mathrm{I}$ & 25 & 14,37 & 1,01 & 0,00 \\
$\operatorname{Tr} 180^{\circ} \mathrm{F}$ & 25 & 14,08 & 0,92 & 0,920 \\
\hline \hline
\end{tabular}

LEGEND: $\mathrm{N}$ - number of respondents; Mean - arithmetic mean; SD - standard deviation; $p$

- level of significance

The implemented program resulted in progress. As it is a relatively short period of time, the progress made is largely the result of better performance techniques. Namely, respondents practiced running mechanics at each training session by performing running athletics exercises that had the goal of achieving optimal length and frequency of steps. Progress is also evident in direction changes in agility tests.

Table 5 - Correlation between initial and final measurements of all three tests

\begin{tabular}{ccccccc} 
Variables & Tr20m I & Tr20m F & TrZZ I & TrZZ F & $\operatorname{Tr} 180^{\circ} \mathrm{I}$ & $\operatorname{Tr} 180^{\circ} \mathrm{F}$ \\
\hline $\operatorname{Tr} 20 \mathrm{~m} \mathrm{I}$ & 1,00 & 0,95 & 0,81 & 0,84 & 0,86 & 0,82 \\
$\operatorname{Tr} 20 \mathrm{~m} \mathrm{~F}$ & 0,95 & 1,00 & 0,82 & 0,85 & 0,89 & 0,84 \\
TrZZ I & 0,81 & 0,82 & 1,00 & 0,96 & 0,86 & 0,84 \\
$\operatorname{Tr} Z \mathrm{~F}$ & 0,84 & 0,85 & 0,96 & 1,00 & 0,87 & 0,85 \\
$\operatorname{Tr} 180^{\circ} \mathrm{I}$ & 0,86 & 0,89 & 0,86 & 0,87 & 1,00 & 0,98 \\
$\operatorname{Tr} 180^{\circ} \mathrm{F}$ & 0,82 & 0,84 & 0,84 & 0,85 & 0,98 & 1,00
\end{tabular}

Little and Williams (2003) analyzed the correlation between running speed and agility (zigzag test) on a sample of professional footballers. Significant but also relatively low correlations $(r<0.70)$ between the tests $(r=0,45)$ were obtained. The authors therefore concluded that the speed and agility of relatively independent qualities and that they require specific training solutions. Unlike the above-mentioned research, high correlation between the tests (Table 5) was obtained in this paper. The correlations indicate that there is no clear differentiation in ability in younger age, but it is mainly to do with universally successful individuals. High correlations were obtained between all three tests in both initial and final measurements. The initial measurement of the $\operatorname{Tr} 180^{\circ}$ test and the final measurement of the $\operatorname{Tr} 20 \mathrm{~m}$ test showed the highest correlation of 0,89 . The lowest correlation between the two different tests is the initial measurement of the Tr20m and TrZZ tests and is 0,81 .

\section{CONCLUSION}

According to the research we can conclude that the speed and agility of young footballers are highly related qualities. It is therefore to assume that speed training will have a significant impact on agility training and vice versa. High correlations point to the fact that in younger age there is no clear distinction of abilities, but it is generally about universally successful individuals. The obtained results are not in line with the research on the population of professional footballers, where as a rule we obtain low correlations between speed and agility, or different agilities. Improvement of the results between the initial and final

Pokrajčić, V., Herceg, L., \& Dugonjić, B., Vojvodić, M. (2018). Effects of speed and agility trainings at young football players. Sportlogia, 14 (1), 59-65. doi:10.5550/sgia.181401.en.phd

Page 63. 
measurements was achieved in all three tests and indicates that the training procedure was effective. However, it remains unclear how these improvements were results of football training itself, and how much of additional content which developed speed and agility. This data will remain deprived because of the fact that the research did not include a control group that would not perform additional contents, but only football training. The probable reason for a significant improvement in all three tests lies in the fact that speed and agility have similar characteristics. The basis of training in methodology of speed and agility training is learning the technique of walking, running, changing direction of movement, economy of movement, etc. Given that the sensitive phase of the development of speed and agility in boys and girls is between the ages of 7 and 11, it is evident why the results of the initial and final measurement were significantly improved. Since they had not met this type of testing earlier, respondents were most likely to advance in the technique, ie. economy of running. The training of young athletes must be considered as a long-term plan by which the increase in load and total physical, technical-tactical and mental demands is applied gradually during the growth and development phases. The foundations of childhood training should be set up through multifaceted development rather than through a narrow, sport-specific training, which will give the young athlete a better base for top performance.

\section{REFERENCE}

Buttifant, D., Graham, K., \& Cross, K. (2001). 55 Agility and speed in soccer players are two different performance parameters. Science and football IV, 4, 329.

Dujmović, P., Elsner, B., \& Fiorentini, F. (2000). Škola nogometa. Zagrebački nogometni savez.

Jozak, R., Segedi, I., Despot, T., Marčeić, Z., Šoš, K., \& Ivanjko, A. (2010). Strength and conditioning training in soccer school Dinamo Zagreb. In I. Jukić, C. Gregov, S. Šalaj, L. Milanović i T. Troš-Bobić (Eds.), 8. godišnja međunarodna konferencija Kondicijska priprema sportaša 2010 (pp. 105-112). Zagreb, HR. Udruga kondicionih trenera Hrvatske i Kineziološki fakultet, Sveučilište u Zagrebu.

Jukić, I. (2016). Razlike $u$ motoričkim znanjima $i$ sposobnostima između selekcionirane $i$ neselekcionirane skupine djece u nogometu. Zagreb, RH: Kineziološki fakultet Sveučilišta u Zagrebu.

Little, T., \& Williams, A. (2003). Specificity of acceleration, maximum speed and agility in professional soccer players, Journal of Strength and Conditioning Research, 19(1), 76-78.

https://doi.org/10.1519/00124278-200502000-00013

https://doi.org/10.1519/14253.1

PMid: 15705049

Mršić, A. \& Jerković, S. (2010.) Nogometni priručnik 3. Đakovo, RH: Andro Mršić.

Spock, B., \& Parker, S. (1998). Dr. Spock's Baby and Child Care. New York City, USA: Pocket Books.

Sporiš, G., Milanović, Z., Trajković, N., \& Joksimović, A. (2011). Correlation between speed, agility and quickness (SAQ) in elite young soccer players. Acta kinesiologica, 5(2), 36-41.

Šamija, K. (2011). Učinci specifičnog treninga brzine $i$ agilnosti (SAQ) na morfološka, motorička $i$ funkcionalna obilježja nogometaša. Doktorska disertacija. Kineziološki fakultet, Sveučilišta u Zagrebu.

Pokrajčić, V., Herceg, L., \& Dugonjić, B., Vojvodić, M. (2018). Effects of speed and agility trainings at young football players. Sportlogia, 14 (1), 59-65. doi:10.5550/sgia.181401.en.phd 


\section{SAŽETAK}

Cilj ovog istraživanja bio je utvrditi napredak $u$ razvoju brzine, agilnosti $i$ eksplozivnosti kod mladih nogometaša. Istraživanje je provedeno na uzorku od 25 mladih

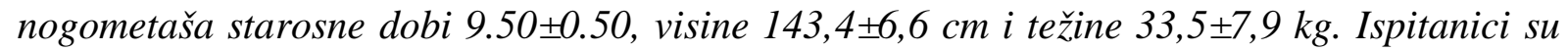
članovi nogometnog kluba „NK Sloga“ iz Ljubuškog, koji treniraju u uzrasnoj kategoriji „Limači (U-11)“. Primijenjeno je ukupno 3 testa: 1. Trčanje na 20 metara iz visokog starta (Tr20m); 2. Trčanje naprijed-nazad s promjenom pod $90^{\circ}(\operatorname{TrNN})$; 3. Zig-zag trčanje između štapova (TrZZ). Analizom razlika (T-test) između inicijalnog i finalnog mjerenja utvrđeno je poboljšanje rezultata. Prosječan rezultat inicijalnog mjerenja trčanja na 20m iznosi 4,43 sekunde dok je prosječan rezultat finalnog mjerenja bolji za 10 stotinki i iznosi 4,33 sekunde. U zig-zag testu prosječan rezultat inicijalnog mjerenja iznosio je 9,34 sekundi, dok je kod finalnog iznosio 9,1 sekundu. Prosječni rezultat popravio se za 0,24 stotinike. U trčanju s promjenom smjera $180^{\circ}$ ispitanici su prosječno trčali 14.37 sekundi u inicijalnom mjerenju, odnosno 14,08 sekundi u finalnom mjerenju. Prosječni rezultat popravio se za 0,29 stotinki. Korelacijskom analizom utvrđeno je da postoji statistički značajna povezanost između sva tri testa. Najveća povezanost između dva različita testa izmjerena je kod inicijalnog mjerenja testa trčanje s promjenom smjera za $180^{\circ}$ i finalnog mjerenja kod testa trčanje na 20 metara $i$ iznosi 0,89.

Ključne riječi: trening, brzina, agilnost, mladi nogometaši

Received: 24.05.2018. Approved: 08.06.2018.

Faculty of Natural Sciences and Mathematics and Education, Mostar, Bosnia and Herzegovina v.pokrajcic@gmail.com

Pokrajčić, V., Herceg, L., \& Dugonjić, B., Vojvodić, M. (2018). Effects of speed and agility trainings at young football players. Sportlogia, 14 (1), 59-65. doi:10.5550/sgia.181401.en.phd

Page 65. 